\title{
Some considerations in economic geography in connection with the war
}

\author{
George G. Chisholm M.A., B.Sc.
}

To cite this article: George G. Chisholm M.A., B.Sc. (1915) Some considerations in economic geography in connection with the war , Scottish Geographical Magazine, 31:2, 82-93, DOI: $10.1080 / 00369221508734178$

To link to this article: http://dx.doi.org/10.1080/00369221508734178

曲 Published online: 27 Feb 2008.

Submit your article to this journal $[\pi$

Џll Article views: 5

Q View related articles 두 


\title{
SOME CONSIDERATIONS IN ECONOMIC GEOGRAPHY IN CONNECTION WITH THE WAR. ${ }^{1}$
}

\author{
By Geonge G. Chisholm, M.A., B.Sc., Lecturer in Geography, \\ Edinburgh University.
}

IN this lecture I intend to confine myself for the most part to considerations connected with the trade of Germany and the United Kingdom. It is, indeed, only a few of the most important effects of the war on the trade of those countries, both generally and in their mutual relations, that can be considered in the course of an ordinary lecture.

I. German Trade in 1913.

\begin{tabular}{|c|c|c|c|c|c|c|c|}
\hline \multicolumn{4}{|c|}{ IMIPORTS. } & \multicolumn{4}{|c|}{ EXPORTS. } \\
\hline$\vdots$ & mil. $£$ & $\%$ & $\begin{array}{l}\text { mil. tons } \\
\text { (metric) }\end{array}$ & & mil. $\mathcal{L}$ & $\%$ & $\begin{array}{l}\text { mil. tons } \\
\text { (metric). }\end{array}$ \\
\hline 1. Grain, & $60 \cdot 8$ & $11 \cdot 4$ & $8 \cdot 3$ & 1. Iron and steel & & & \\
\hline 2. Raw cotton, & 20.4 & $5 \cdot 5$ & 0.5 & implements, & $67 \cdot 0$ & $13 \cdot 3$ & $6 \cdot 5$ \\
\hline 3. Raw hides and & & & & 2. Machinery, & $33 \cdot 9$ & $6 \cdot 7$ & 0.6 \\
\hline skins, - & $22 \cdot 6$ & $4 \cdot 2$ & 0.2 & 3. Coal and coke, & $32 \cdot 3$ & $6 \cdot 4$ & $41 \cdot 0$ \\
\hline $\begin{array}{l}\text { 4. Oil seeds and } \\
\text { spirits. }\end{array}$ & 9.. & 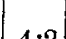 & & 4. Grain, - & $: 19 \cdot 8$ & $\mathbf{3} \cdot \mathbf{9}$ & $2 \cdot 5$ \\
\hline 5. Raw wool, & $18 \cdot 4$ & $\begin{array}{l}4 \cdot 2 \\
3 \cdot 5\end{array}$ & 02 & $\begin{array}{l}\text { 5. Cottons, } \\
\text { Dyed, printed, }\end{array}$ & סיר & $3 y$ & $0 \cdot 1$ \\
\hline 6. Copper, & $17 \cdot 6$ & $3 \cdot 3$ & $0 \cdot 2$ & etc., & $\vdots 6 \cdot 3$ & $1 \cdot 3$ & $\cdots$ \\
\hline 7. Cotfee, ; & $12 \cdot 5$ & $2 \cdot 3$ & $0 \cdot 2$ & 6. Electro-techni- & & & \\
\hline 8. Pine wood, & $12 \cdot 4$ & $2 \cdot 3$ & $4 \cdot 9$ & cal products, & $14 \cdot 5$ & $2 \cdot 9$ & 0.1 \\
\hline 9. Iron ore, - & $11 \cdot 6$ & $2 \cdot 2$ & $14 \cdot 0$ & 7. Chemicals, & $14 \cdot 5$ & $2 \cdot 9$ & $\ldots$ \\
\hline 10. Animals,. & $9 \cdot 9$ & $1 \cdot 9$ & & Coal-tar dyes, & $8 \cdot 2$ & $1 \cdot 6$ & \\
\hline 12. Coal, - & $9 \cdot 7$ & 1.8 & $10 \cdot 5$ & 8. Sugar, - & $13 \cdot 2$ & $2 \cdot 6$ & $1 \cdot 1$ \\
\hline $\begin{array}{l}\text { 14. Yarn, cotton, } \\
\text { and wool, }\end{array}$ & 8.8 & 1.6 & & 9. Woollens, & $\begin{array}{l}12 \cdot 0 \\
10 \cdot 1\end{array}$ & $2 \cdot 0$ & $\cdots$ \\
\hline 15. Nitrate of soda, & $8 \cdot 5$ & $1 \cdot 6$ & $0 \ddot{0}$ & 15. Silks and half & & & $\cdots$ \\
\hline Tin,. . . & $3 \cdot 0$ & 0.6 & $\ldots$ & silks,. & $6 \cdot 2$ & 1.2 & $\ldots$ \\
\hline Tin-plate, & 0.6 & $0 \cdot 1$ & & $\begin{array}{l}\text { 18. Hides, skins, } \\
\text { raw, }\end{array}$ & $5 \cdot 2$ & 1.0 &. \\
\hline Total, & 535 & 100 & $\cdots$ & & 504 & 100 & 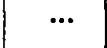 \\
\hline
\end{tabular}

In this and other tables designed merely to indicate rougbly the order of importance the mark is converted at 1s., not at the more precise equivalent of $11 \cdot 8 \mathrm{~d}$., now adopted by the Board of Trade.

Table I. exhibits the leading items in addition to some other items of special interest in the trade of Germany, according to the preliminary returns for 1913. From this you will see that the trade of Germany has, on the whole, a great similarity to our own, showing a marked predominance among the imports of food stuffs and raw materials, and among the exports of manufactured goods,

i A Lecture delivered to the Royal Scottish Geographical Society on the 16th of December 1914. 
together with coal and coke, although on this side one must note also a considerable export of grain as well as of sugar, which, although it involves manufacturing processes, is nevertheless also a product of German agriculture. This correspondence between the trade of the two countries, it may be mentioned, is of comparatively recent development. In the early years of the German Empire by far the most important item in the exports of the Empire was grain, and the exports of iron and steel manufactures, machinery, coal and coke, chemicals, and of most of the other manufactures that you will see in this list, were insignificant. This change is often set down as one of the results of the formation of the Empire, but I have already, in another lecture delivered to this Society, indicated, at least to some extent, my reasons for believing that the rapid growth of German manufactures and commerce after the proclamation of the Empire was mainly a coincidence, and was in fact only in small part promoted by the circumstances that gave rise to the Empire. The fact is that for reasons which it would be out of place to enter into here, the development of the resources of Germany by modern methods happened to be very backward in the early seventies of the last century, and it was only about that time that those methods came to be applied to bring about that development. Already, it must be remembered, Germany was provided with an able and highly educated population, and in these circumstances it was certainly not to be wondered at that the development should have then proceeded with great rapidity. As in our own country, the first two imports are now grain and raw cotton, in that order, and it is somewhat striking that grain bears very nearly the same proportion to the total imports as it does in the commerce of the United Kingdom; but in making this comparison you must note that the proportion of the external trade of Germany to the internal is far from so great as with us, so that the 11.4 per cent. that you see in the table for the grain import has not the same significance as a corresponding percentage in the trade of our own country. Among the grains imported into Germany the most important are barley and wheat. The import of rye, which is the principal bread plant in Germany, is insignificant, and since 1908 has been more than balanced by the export under the same head. The wheat import is in Germany equal to only one-third of the total consumption, ${ }^{1}$ instead of about four-fifths as with us ; the import of barley, on the other hand, is nearly a half of the total requirement. ${ }^{2}$ In both cases the import is accordingly large and raises the question as to whether Germany is likely to be seriously embarrassed by a prolonged war through any deficiency arising in her food supply. Officially it was estimated by the Germans that they had

1 Average of the seven years 1907.1913 following the imposition of the enhanced import duties which began to be levied on March 1, 1906 (German seed grain excluded).

2 For the same period 48 per cent. It should be added that the proportions of import to consumption given in the text are based on the assumption that the German official estimates of the yield of bread-grains are approximately accurate, whereas Dr. Ballod gives in the article cited below in the text (pp. 132-4) reasons for believing that they are much exaggerated, in some cases by more than one-fifth. These reasons, however, are called in question by Count Von Noltke in an article in the August number of the Preussische Jahröucher, pp. 297-8. 
at the beginning of the war enough rye to meet a year's consumption, and enough wheat to meet a consumption of eleven months; and it was considered unlikely that Germany would be wholly cut off from fresh supplies when the war broke out. Still it is worth while to look to Germany's sources of supply, and we find that more than half of Germany's import of wheat comes from Russia, which also furnishes Germany with nearly seven-eighths of her imported barley. That source of supply is in both cases cut off by the war, and although no doubt both wheat and barley may be got elsewhere we shall afterwards consider what Germany's difficulties in replacing the Russian contributions are likely to be. But, as was pointed out by a German economist, Dr. Carl Ballod, Professor of Political Science in the University of Berlin, and a member of the Royal Prussian Land Office, in an article that appeared in the Preussische Jahrbiicher for last July, shortly before the outbreak of the war, the question of food supply is not a simple one. It may be true that if all the wheat and rye actually existing in Germany at that time, or likely to exist at the end of the harvest, were available for human consumption, then the anticipation as to the period for which rye and wheat would respectively hold out might be fulfilled, but Dr. Ballod points out, as some of you may remember to have seen stated in the Scotsman, that Germany needs to import 60 per cent. of the food required for cattle and stock in general, these supplies coming in the form of coarser grains, as well as fodder of other kinds. And he adds that if the Germans were reduced to their own resources for the feeding of those animals the milch cows would thereby be diminished to one-third of their value, at least as milk producers. Further, two-thirds of the pigs, which form a very much more important element in the live stock in Germany than in that of the United Kingdom, could not be fattened and would be killed and put out of account as rapidly as possible. ${ }^{1}$ The general result would be that the available quantity of butcher meat would, sooner or later, come to be diminished, and therefore the consumption of bread would be augmented in the same proportion, so that the stock of bread plants would need to be largely increased in order to meet this increased demand. That Germany was already beginning to feel the need for economising her resources about the end of October is apparent from the fact that an official order was then issued regulating the prices and to some extent the use of bread-grains. The usual imports of fodder barley from Russia being stopped, the more valuable German barley began to rise in price, and rye was substituted as a fodder crop. A Government decree accordingly declared that the maximum price for barley should be less than that for rye, and that all bakers should make bread of mixed flour; that wheaten bread should contain at least 10 per cent. of rye flour, and rye bread at least 5 per cent. of potatoes, as much as 20 per cent. being permitted. Maximum prices were fixed for different parts of the Empire,

3 Count von Moltke in the article cited in note 2 on p. 83 , argues (pp. 298-9) that it is unnecessary to maintain the numbers of the live stock in war-time, but it is difficult to see how in that case he can evade Dr. Ballod's conclusions as to the result of such reduction in numbers. 
so as to allow for the cost of carriage from the source of supply. The maximum for rye was to be equal to $£ 11$ per ton at Berlin, $£ 10,9 \mathrm{~s}$. at Königsberg, £11, 17s. at Munich, Aachen, and Strassburg. These prices were to hold good from November 4 to December 31, 1914, after which there was to be a rise of $1 \mathrm{~s}$. $6 \mathrm{~d}$, per ton every fortnight. These measures, it is true, need not be taken as showing any actual need at present, but are put forward simply as a means to ensure foresight on the part of the people, and to prevent them from encroaching too rapidly upon their resources. But the difficulty of adequately feeding their live stock has been generally foreseen in Germany. It would appear to be indicated by the low meat prices there early in the war, these being attributed to the fact that large numbers of live stock were killed off owing to the increasing price of food stuffs, and if that is so, that period of abundance and low prices is likely to prove a forerunner of scarcity and excessively high prices in future.

Then, further, if the war should be prolonged beyond a year and Germany should come to depend upon her own resources, or almost entirely upon her own resources, for a second year's supply of food, there is one feature in German agriculture which seems to me of great significance, viz., that already quite an exceptional proportion of the agricultural labour of Germany is performed by women. The three occupation censuses that have taken place in Germany, in 1882, 1895, and 1907 respectively, have shown a rapid increase in this proportion, and although part of this increase is undoubtedly due to the fact that agricultural employees belonging to the families of the farmers had not at one time been registered as employees, but took care to have themselves so registered after the passing of the insurance legislation of Germany, so that they might take advantage of that legislation, still the growth is to some extent real, and at any rate the proportion as compared with our own country is very large, at the census of 1907 being equal to 47 per cent. of the total number of agricultural employees. Now the male agricultural population must certainly be drawn upon to a considerable extent to fill the armies in the field. If it is true that the proportion of agricultural employees withdrawn for military service is not so high as in other industries owing to their higher average age, still Dr. Ballod estimates ${ }^{1}$ that in round numbers $1,000,000$ agricultural labourers must be drafted to the colours, say one in five. In similar circumstances in other agricultural countries the labour thus lost is often to a large extent made good by the employment of female labour, but in Germany it is difficult to suppose that there is a large reserve of female labour to draw upon. These considerations make it extremely doubtful whether there could be next year anything like as large a production of food stuffs in Germany as in the year which has furnished the supplies now being used. It would indeed be, as always, hazardous to prophesy, but it seems likely that if we are able to retain the command of the sea, Germany, even if we consider merely the food supply, will be less able to hold out than we are. 
Now for some of the other imports. Next to our own country Germany is the largest consumer, outside the United States, of raw cotton. The bulk of that comes indeed from the United States but about a quarter comes from British India and Egypt, a supply that is likely to be totally cut off. Of the whole supply about 40 per cent. comes from British India and Egypt. More than 50 per cent. of all the wool imported into Germany comes from British possessions. Among animals, the horses come in considerable numbers, and pigs and geese almost entirely from Russia. Russia is also the source of more than two-fifths of the wood supply of Germany, and of the coal which Germany imports five-sixths comes from the United Kingdom. It will thus be seen that, if we look merely at the ordinary countries of origin, without considering the difficulties of trade generally that Germany has to encounter, a large proportion of their supplies of raw materials is likely to be cut off. If that is so there will be an increasing difficulty in keeping the population not in arms employed. The ordinary mechanism of commerce and trade will be to a large extent destroyed, and in that way the ordinary means of distribution of income will be put out of working. Even, therefore, if food still continued to be available for the population, an increasing proportion of the inhabitants would become unable to procure their food in the ordinary way, and would be thrown for support upon state organisations. ${ }^{1}$ The export market will also be similarly interfered with to a large extent. The United Kingdom is the principal market for about three-fourths of the sugar exported by Germany. For the iron and steel manufactures of Germany the principal markets are Great Britain and Russia ; of the machinery which Germany exports, Russia, France, Belgium and Great Britain take in all above one-third. For the electro-technical and chemical products exported by Germany, Great Britain is the largest market, and Russia and France together take an amount exceeding that of Great Britain.

Now look at the third column in Table I. Notice the articles which bulk largely among the imports and exports in respect of quantity. You will see on the import side these are iron ore, coal, grain and wood, followed at a considerable distance by nitrate of soda. Now these are all mainly-nitrate of soda wholly-imported by sea. Among exports the iron and steel manufactures, and the grain, are also to be noted among the bulky products exported mainly by water. On the other hand, the coal and coke now so largely exported principally goes by land or inland waterways, about one-third of it finding its way into Austria-Hungary, the countries next in order of importance as receiving German coal being the others immediately adjoining. Still an increasing proportion of this article also is now exported by sea. I draw special attention to this, because trade in bulky articles is unquestionably one of the important causes promoting the growth of shipping, and hence it is not surprising to see with what rapidity the German mercantile marine has grown within recent years, as shown in Table II.

1 Towards the end of January 1915, it was officially announced that on February 1 all the corn and flour in Germany would be seized by the Government with a view to the distribution of these commodities by the State in proportion to population. 
And here we have to consider another effect of the war, very serious for Germany. During the whole war we have been learning from time to time, with great regret, the loss. which the German fleet has been able to inflict upon British shipping. But after all that is no more than what was foreseen and provided for; it would appear, from the profitable nature of the business which the Government is said to be carrying on in marine insurance, amply provided for. ${ }^{1}$ The loss that this country has thereby incurred is small compared with that which is suffered by the German mercantile marine through its being absolutely unable to venture to sea, except on the home waters. It is reported that one large German shipping company, said to be the greatest cargo steam shipping company in the world, has had to resort to the method of chartering ships flying the flags of Norway, Holland, America, and even of Great Britain, in order merely to preserve its organisation, its own shipping having been either seized or laid up in neutral ports. It was probably the same German company which lamented that, in consequence of their seventy ships being laid up, they found five thousand men on

\section{Steant Tonnage-United Kingdonr and Germany. Thousands of Tons (000 omitted).}

\begin{tabular}{|c|c|c|c|}
\hline Years. & United Kingdom. & Germany. & $\begin{array}{c}\text { German percentage } \\
\text { of aggregate. }\end{array}$ \\
\hline 1872 & 1,538 & 130 & $7 \cdot 8 \%$ \\
1882 & 3,335 & 311 & $8 \cdot 5, "$ \\
1892 & 5,564 & 786 & $12 \cdot 4, "$ \\
1902 & 8,104 & 1622 & $16 \cdot 7, "$ \\
1912 & 10,992 & 2655 & $19 \cdot 5, "$ \\
\hline
\end{tabular}

their hands for maintenance, these including many Lascars, accordingly British subjects, engaged for a period of years, after which they have to be returned under contract to India. Table III. shows how enormously Germany has suffered under this head as compared with the United Kingdom.

At Table IV, showing the proportion of German trade for 1912 with different countries (under this head I know of no later figures already available), I will ask you to look more briefly. But by way of supplement I may add that if we consider the trade carried on with enemy countries as wholly lost, and take the year 1912 as a standard of reference, then we find on the import side that Germany would lose in a year about $£ 236,000,000$ of trade, or more than 44 per cent. of the total ; on the export side, $£ 181,000,000$, or upwards of 40 per cent. of the total; whereas the corresponding loss to the United Kingdom would be about $£ 84,000,000$, or a little more than 11 per cent. on

1 This is pretty clearly indicated by the rapid reduction in the insurance preminm. The Government rate for cargoes was fixed at five guineas on August 5, 1914, and was reduced to four guineas on August 8, to three guineas on August 18, to two guineas on August 31, and to one guinea at the end of the year. 
the import side, and $£ 66,000,000$, or under 11 per cent. on the export side:

But the matter is not so simple. It may be taken as absolutely certain that the loss of trade to both countries will be at a higher rate than that indicated. In the first four months of the war the loss in imports to the United Kingdom has been nearly $£ 63,000,000$, in exports nearly $£ 84,000,000$, in all above $£ 146,000,000$ as compared with the corresponding period of last year. ${ }^{1}$ Germany's loss must be increased in a still greater ratio. For let us consider the trade of Germany with neutral countries. First we have to note that owing to the British blockade the most important German seaports, Hamburg and Bremen, as well as Emden, are hardly available. On the Baltic, it is true,

III. Navy's EFfective Work.

(Board of Trade, 26th November 1914.)

\begin{tabular}{|c|c|c|c|c|c|c|c|c|}
\hline & \multicolumn{4}{|c|}{ UNITED KINGDON. } & \multicolumn{4}{|c|}{ Germany. } \\
\hline & No. & $\%$ & $\begin{array}{l}\text { Tonnage. } \\
000 \text { omitted. }\end{array}$ & $\%$ & No. & $\%$ & $\begin{array}{c}\text { Tonnare. } \\
000 \text { omitted. }\end{array}$ & $\%$ \\
\hline Total of ships over & & & & & & & & \\
\hline 100 tons gross, & 10,123 & 100 & 20,524 & 100 & 2090 & 100 & 5,132 & 100 \\
\hline Unavailable, & 195 & $1 \cdot 9$ & 586 & $2 \cdot 9$ & 1221 & $58 \cdot 4$ & 4,585 & $89 \cdot 3$ \\
\hline $\begin{array}{l}\text { Captured, } \\
\text { Detained in }\end{array}$ & 49 & $\cdots$ & $\cdots$ & $\cdots$ & 80 & $\cdots$ & $\cdots$ & $\cdots$ \\
\hline $\begin{array}{l}\text { enemy ports, } \\
\text { Held up in neut. }\end{array}$ & 75 & ... & $\cdots$ & ... & 166 & ... & ... & $\cdots$ \\
\hline ral ports, etc. & 71 & $\cdots$ & $\cdots$ & ... & $\begin{array}{l}646 \\
329\end{array}$ & $\begin{array}{l}\text { (neut } \\
\text { (Ger }\end{array}$ & $\begin{array}{l}\text { ral ports) } \\
\text { man ports) }\end{array}$ & \\
\hline $\begin{array}{l}\text { Still plying, } \\
\text { Known to be at }\end{array}$ & 9928 & $98 \cdot 1$ & 20,122 & $97 \cdot 1$ & 869 & $41 \cdot 9$ & 55 & $10 \cdot 7$ \\
\hline $\begin{array}{l}\text { sea, } \\
\text { Ships over } 50 \dot{0} \\
\text { tons not ac- }\end{array}$ & $\cdots$ & ... & $\cdots$ & $\cdots$ & 10 & $\cdots$ & ... & $\cdots$ \\
\hline $\begin{array}{l}\text { counted for, } \\
\text { Steam trawlers, }\end{array}$ & $\begin{array}{l}\cdots \\
\cdots\end{array}$ & $\begin{array}{l}\ldots \\
\ldots\end{array}$ & $\begin{array}{l}\ldots \\
\ldots .\end{array}$ & $\begin{array}{l}\cdots \\
\cdots\end{array}$ & $\begin{array}{l}125 \\
353\end{array}$ & $\begin{array}{l}\ldots \\
\ldots\end{array}$ & $\begin{array}{l}\cdots \\
\ldots\end{array}$ & $\begin{array}{l}\ldots \\
\ldots\end{array}$ \\
\hline Small coasters, & ... & $\ldots$ & ... & $\cdots$ & 381 & ... & ... & ... \\
\hline
\end{tabular}

Germany still has command of the sea, and can make use, therefore, of the ports of Stettin, Königsberg, Danzig, Lübeck, and others, but for her oceanic trade she is thrown back upon the Austrian port of Trieste, and neutral ports such as Rotterdam, Copenhagen, and Genoa, as well as Scandinavian ports by means of which her own Baltic ports can be reached. Of all these the most important of course to Germany is Rotterdam, how much the most important we shall understand better from the light which we shall get from a subsequent table. The routes by Scandinavia and Italy are not only devious, but must be made even more expensive by the heavy gradients that have to be overcome when they are followed. That from Genoa to the Rhine valley involves

1 Down to the end of the year, first five months of war, the corresponding loss was. $£ 67,000,000$ in imports, $£ 105,000,000$ in exports-together $£ 172,000,000$. 
the climbing of three mountain ranges and the use of three mountain tunnels-through the Apennines, immediately behind Genoa, through the Alps by St. Gothard, and through the Jura by the Hauenstein, where the gradient adds so much to the cost of working the railway that a new tunnel is now being made at base level.

Then one has to bear in mind that neither British nor German shipping will be available for carrying on the trade between Germany and the neutral countries for the reasons already seen. That a serious difficulty is created by the fact that British shipping will not be available for the purpose will be understood when one bears in mind that even when the German shipping held the seas, British shipping made up considerably more than 40 per cent. of the total shipping of the world and obviously, therefore, it makes up a much larger proportion of that which is now employed. And, further, the trade that is carried on by means of neutral shipping is subject to being interfered with in respect

IV. German Traide, 1912.

\begin{tabular}{|c|c|c|c|c|c|}
\hline \multicolumn{3}{|l|}{ IMPORTS. } & \multicolumn{3}{|l|}{ Exports. } \\
\hline & mil. $\&$ & $\%$ & & mil. $\&$ & $\%$ \\
\hline $\begin{array}{l}\text { 1. United States, . } \\
\text { 2. Russia, } \\
\text { 3. United Kingdom, } \\
\text { 4. Austria-Hungary, } \\
\text { 5. France, } \\
\text { 6. British India, : } \\
\text { 7. Argentina, : } \\
\text { 8. Belgium, : } \\
\text { 9. Netherlands, : } \\
\text { 10. Brazil, : : } \\
\text { 11. Italy, : : } \\
\text { 12. Australia, } \text { Total, }\end{array}$ & $\begin{array}{l}79 \cdot 3 \\
76 \cdot 4 \\
42 \cdot 1 \\
41 \cdot 5 \\
27 \cdot 6 \\
26 \cdot 7 \\
22 \cdot 2 \\
19 \cdot 3 \\
17 \cdot 3 \\
15 \cdot 7 \\
15 \cdot 2 \\
13 \cdot 8 \\
535\end{array}$ & $\begin{array}{r}14 \cdot 8 \\
14 \cdot 3 \\
7 \cdot 9 \\
7 \cdot 8 \\
5 \cdot 2 \\
5 \cdot 0 \\
4 \cdot 2 \\
3 \cdot 6 \\
3 \cdot 2 \\
2 \cdot 9 \\
2 \cdot 9 \\
2 \cdot 6 \\
100\end{array}$ & $\begin{array}{l}\text { 1. United Kingdom, } \\
\text { 2. Austria-Hungary, } \\
\text { 3. United States, : } \\
\text { 4. France, : } \\
\text { 5. Russia, : } \\
\text { 6. Netherlands, : } \\
\text { 7. Switzerland, : } \\
\text { 8. Belgium, : : } \\
\text { 9. Italy, : : } \\
\text { 10. Denmark, : } \\
\text { 11. Argentina, : } \\
\text { 12. Sweden, ' Total, }\end{array}$ & $\begin{array}{r}58 \cdot 1 \\
51 \cdot 8 \\
34 \cdot 9 \\
34 \cdot 5 \\
34 \cdot 0 \\
30 \cdot 4 \\
26 \cdot 0 \\
24 \cdot 7 \\
20 \cdot 1 \\
12 \cdot 7 \\
12 \cdot 0 \\
9 \cdot 9 \\
448\end{array}$ & $\begin{array}{r}13 \cdot 0 \\
11 \cdot 6 \\
7 \cdot 8 \\
7 \cdot 7 \\
7 \cdot 6 \\
6 \cdot 8 \\
5 \cdot 8 \\
5 \cdot 5 \\
4 \cdot 5 \\
2 \cdot 8 \\
2 \cdot 7 \\
2 \cdot 2 \\
100\end{array}$ \\
\hline
\end{tabular}

of contraband articles, among which, in accordance with an order in Council promulgated on the 29th of October, are included, among other things, all food stuffs as conditional contraband, and motor spirit, and oils capable of being used for the same purpose, beside nickel ore, nickel, ferro-chrome, chrome ore, copper, aluminium, and ferro-silica, all these being minerals badly needed by Germany for the manufacture of the implements of war, as absolute contraband. By a previous order in Council issued two days before, the convention known as the Declaration of London, a convention that had never been formally ratified, but which in the beginning of the war the Government had intimated its intention of adhering to so far as practicable, had been abandoned to such an extent as to allow of the capture of contraband articles in neutral vessels when such articles were clearly intended for enemy countries, and to render a neutral vessel liable to capture and condemnation in the event of her going to an enemy port, notwithstanding a

VOL. XXXI. 
different destination shown in her papers, if she should be captured before the end of her next voyage. In addition to that the British Government has prohibited the export of a large number of articles, including saltpetre, nitrate of sodium, soft paraffin, confectionery, tea, wool and woollen manufactures, leather, pig-skins, hides, hemp, cordage and twine, and a number of other articles which should be of special importance to Germany in the present circumstances. In some cases these regulations have been modified, but only under conditions that would seem to preclude all possibility of the exported goods reaching an enemy country.

Let us look now at Table V. showing the leading exports from the United Kingdom to Germany. I must deal with it very briefly,

V. United Kingdon Exponts to Germany.

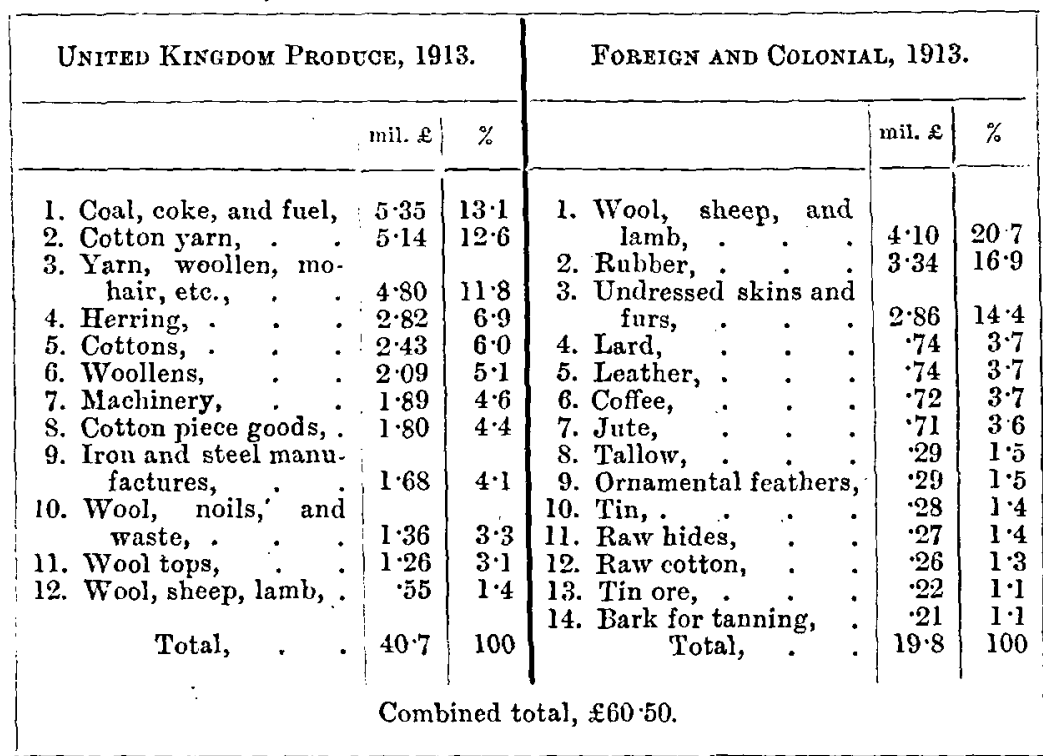

but I would point out that cotton and other. yarns in the aggregate make up by far the most important item, amounting to one-fourth of the total value of those exports. The German textile industry is, and always has been, to a very large extent dependent upon this country, at least for the finer cotton yarns, and, in the woollen trade, for those yarns which are distinguished as worsted. The cotton industry of Germany, for various reasons, including climatic ones, concerns itself chiefly with the production of the coarser yarns, and it is on that account that Germany imports such a large proportion of Indian raw cotton, which furnishes suitable material for that branch of the industry, finer yarns having long been becoming more and more the Lancashire specialty, and though these can to some extent be replaced from Switzerland, still the Swiss industry is far from being on a suff- 
ciently large scale to make good the deficiency. Worsted yarns are also a great English specialty, their production being carried on to a larger extent in Bradford than anywhere else in the world. It is an industry that involves great capital and a high degree of organisation, and nowhere else at the present time is that combination to be found to the same extent.

Table VI. shows the effect of the war in the case of a commodity of quite special importance in the industry and commerce of Great Britain. Coal-mining is the British industry that employs the largest number of people next to agriculture, and these, it must be remembered, nearly all men. Probably it is the industry in which the largest pro-

\section{CoAl Exports, United Kingdon.}

Quantity in Million Tons.

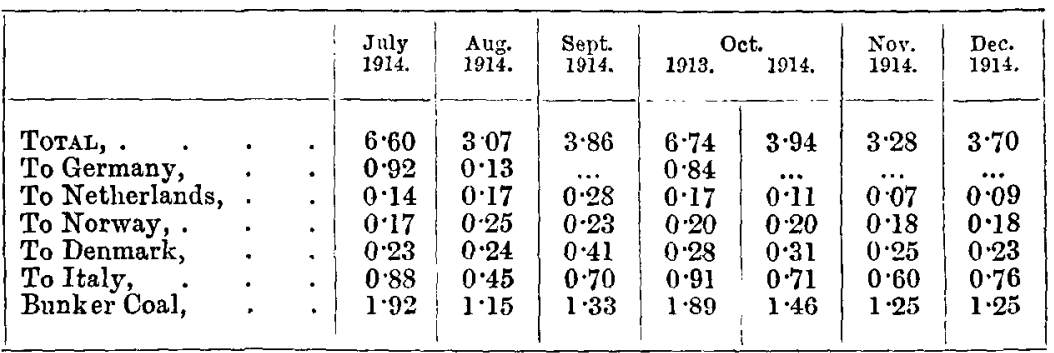

Average Export Price per Ton.

\begin{tabular}{|c|c|c|c|c|c|c|c|c|}
\hline & & $\begin{array}{l}\text { July } \\
\text { I91. }\end{array}$ & $\begin{array}{l}\text { Aug. } \\
\text { I914. }\end{array}$ & $\begin{array}{l}\text { Sept. } \\
1914 .\end{array}$ & 1913. & 1914. & $\begin{array}{l}\text { Nov. } \\
1914 .\end{array}$ & $\begin{array}{l}\text { Dec. } \\
1914 .\end{array}$ \\
\hline $\begin{array}{l}\text { TotaL, } \\
\text { To Germany, } \\
\text { To Italy, }\end{array}$ & $\dot{\cdot} \quad \dot{ }$ & $\begin{array}{c}\text { sh. } \\
13.5 \\
11 \cdot 6 \\
14.3\end{array}$ & $\begin{array}{c}\text { sh. } \\
\ldots . \\
\ldots \\
\ldots\end{array}$ & $\begin{array}{c}\text { sh. } \\
\ldots \\
\ldots \\
\ldots\end{array}$ & $\begin{array}{c}\text { sh. } \\
\ldots \\
\ddot{13} \cdot 2\end{array}$ & $\begin{array}{c}\text { sh. } \\
13 \cdot 2 \\
\ldots \\
\ldots\end{array}$ & $\begin{array}{c}\text { sh. } \\
13 \cdot 2 \\
\ldots \\
\cdots\end{array}$ & $\begin{array}{c}\text { sh. } \\
\mathbf{I 3} \cdot 3 \\
\ldots \\
\ldots\end{array}$ \\
\hline
\end{tabular}

portion of the value of the product is represented, at least at the pitmouth, by the wages of those employed. As an article of commerce, while it stands among the leading exports in respect of value, it is incomparably the most important as regards quantity. It furnishes the cargo for much more than half the aggregate tonnage of laden vessels leaving the ports of the United Kingdom. For this commodity, as the table shows, Germany is one of the two leading markets. But the table makes it plain that great losses under this head have been suffered elsewhere also, and the nature of that loss is largely indicated by the last two lines in the table. Much of the coal sent to Italy is bunker coal, that is, coal designed for the use of steamers, and the great reduction in this export is an indication of the injury done by the war to ocean commerce generally as well as the manufacturing industry of many countries. 
The export of herrings is a trade that greatly affects Scotland, and in particular the city of Aberdeen. The Baltic has always been the great external market for salted herrings, and Table VII. reveals how severely this trade has been hit by the virtual closing of that sea.

VII. United Kingdon Export of Cured or Salitei Herrings.

Thousands of Cwts.

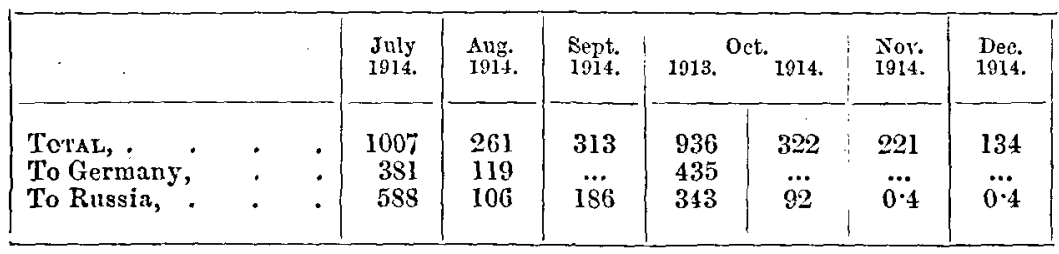

Now look at Table YIII. showing the leading imports from Germany:-

VIII. UNITED KINGDOM IMPORTS FROM GERMANT, 1913.

\begin{tabular}{|c|c|c|c|c|}
\hline & & mil. $£$ & $\%$ & $\%$ imported direct in 1912. \\
\hline $\begin{array}{l}\text { 1. Iron and steel, includir } \\
\text { 2. Sugar, refined, } \\
\text { 3. Sugar, unrefined, } \\
\text { Silks and half silks, } \\
\text { 4. Machinery, : : } \\
\text { 5. Grain, : } \\
\text { 6. Woollens, : : } \\
\text { 7. Cotton piece goods, } \\
\text { 8. Leather, } \\
\text { 9. Cotton hosiery, : } \\
\text { 10. Chemicals, : } \\
\text { 11. Silk broadstuts, : } \\
\text { 12. Coal tar dyes, : } \\
\text { 13. Electrical goods, : } \\
\end{array}$ & 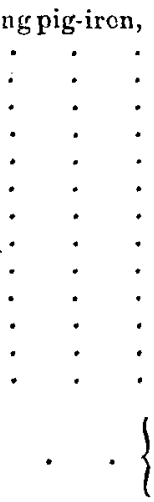 & $\begin{array}{r}7 \cdot 8 \\
6 \cdot 2 \\
4 \cdot 7 \\
2 \cdot 4 \\
2 \cdot 4 \\
2 \cdot 2 \\
2 \cdot 1 \\
2 \cdot 0 \\
1 \cdot 9 \\
1 \cdot 9 \\
1 \cdot 9 \\
1 \cdot 8 \\
1 \cdot 7 \\
\cdot 9 \\
\\
80 \cdot 4\end{array}$ & $\begin{array}{l}9 \cdot 7 \\
7 \cdot 7 \\
5 \cdot 9 \\
3 \cdot 0 \\
3 \cdot 0 \\
2 \cdot 7 \\
2 \cdot 6 \\
2 \cdot 4 \\
2 \cdot 4 \\
2 \cdot 3 \\
2 \cdot 3 \\
2 \cdot 2 \\
2 \cdot 1 \\
1 \cdot 2 \\
100\end{array}$ & $\begin{array}{l}9 \\
180 \\
102 \\
55 \\
43 \\
32 \\
30 \\
53 \\
6 \\
0 \cdot 5 \\
15 \\
\\
\% \text { by different rontes. } \\
52 \cdot 5 \text { direct. } \\
33 \cdot 0 \text { via Netherlands. } \\
13 \cdot 0 \text {, Belgium. }\end{array}$ \\
\hline
\end{tabular}

I will enter for the present into no details so far as the first two columns are concerned, inasmuch as the more special considerations I have to lay before you with regard to them will be more conveniently dealt with after you have seen a subsequent table; but $I$ ask you to notice the great importance of the iron and steel, sugar and chemical imports, including coal tar dyes. I wish, however, to draw your attention to the figures that you sce in the third column and at the foot of the table. These give a very striking indication of the mode in which Germany carries on its trade, not merely with this country, but with other countries beyond the North Sea. In some cases, you will observe, only a very small proportion of the imports from Germany into this country 
come to us directly from Germany, that is to say, from German ports. In 1912 more than 90 per cent. of the iron and steel imports and chemicals, excluding coal tar dyes, came to us through other countries, and the figures at the bottom show the routes by which this trade was really carried on, probably, you may say, by Rotterdam and Antwerp. The reason for that is obvious. By far the most important manufacturing region in Germany is that of the Ruhr basin and the Rhine, situated almost due east of Antwerp, and accordingly for the products of that region destined for this country, whether sent by water or by rail, one or other of these two ports, or some other Dutch or Belgian port (the Hook of Holland or Flushing in the one case, Ostend in the other), is by far the most convenient place for their dispatch. And of course it is obvious that the reverse holds good in the case of imports into Germany, although the tables of our commerce do not allow of our making a similar statement with regard to these. The importance of this consideration is enhanced when one bears in mind that the river Rhine may probably be described as, in the present circumstances, the most advantageous river for commerce in the world, and that that river is connected by waterways allowing of the use of barges of at least 1500 tons burden even with Antwerp. When this is considered one cannot but perceive how desirable must appear the possession of both the Netherlands and Bolgium in the eyes of Germany. But it will be at the same time evident that, during the present war at any rate, the advantage of Germany lies in observing the neutrality of Holland. If that were once violated the Allies would then be in a position completely to stop all trade by means of the Rhine. According to the Rhine Act of 1868 all goods that arrive at Rotterdam on a through bill of lading for Germany, or sent to the ordinary merchant declaring that they are in transit, must be sent on across the Dutch frontier. Hence the care which the Allies have to take in seeing that all contraband, or conditional contraband, is stopped before reaching that port at all. The fact here referred to also makes clear what a vital thing it is for Germany to keep the war away from the Rhine, especially near the Dutch frontier.

There is no time to comment on the proportions of the different commodities imported direct into this country in most cases, but I must make an explanation with regard to the percentage put down in the case of sugar. What is meant by the figures you there see is that the total amount of sugar that comes to this country from German ports is considerably more than, in the case of refined sugar, about four-fifths as much again as that of German origin. The explanation of that is that the great sugar-growing regions of the continent which supply this country are Central or South-East Germany, and the Austrian province of Bohemia. Now these are regions that are inevitably served by the port of Hamburg, or perhaps also that of Bremen, both in any case German ports. A great quantity of the sugar that comes from Germany is of Austrian origin.

(To be continued.) 